NBER WORKING PAPER SERIES

\title{
MONEY, IMPERFECT INFORMATION \\ AND ECONOMIC FLUCTUATIONS
}

\author{
Bruce Greenwald \\ Joseph E. Stiglitz
}

Working Paper No. 2188

\author{
NATIONAL BUREAU OF ECONOMIC RESEARCH \\ 1050 Massachusetts Avenue \\ Cambridge, MA 02138 \\ March 1987
}

The research reported here is part of the NBER's research program in Economic Fluctuations. Any opinions expressed are those of the authors and not those of the National Bureau of Economic Research. 
NBER Working Paper \#2188 March 1987

Money, Imperfect Information and Economic Fluctuations

\section{$\underline{\text { ABSTRACT }}$}

This paper summarizes the macro-economic and, in particular, monetary and financial market implications of recent developments in the micro-economic theory of imperfect information. These micro-economic models which lead to credit-rationing on the one hand and limitations in the availability of equity type financing on the other can account for a wide range of observed business cycle and monetary phenomena. These include (a) unemployment, (b) the existence of Keynesian-type multiples, (c) the observed lack of production smoothing in response to cyclical fluctuations in demand, (d) the impact of monetary policy on business activity despite the absence of significant changes in real interest rates, and (e) price rigidities which arise from rational firm decisions (not as an a priori assumption).

Bruce Greenwald

Bell Communications Research

Morristown, NJ 07960
Joseph E. Stiglitz

Princeton University

Princeton, NJ 08544 


\section{Preliminary Draft \\ Money, Imperfect Information, and Economic Fluctuations ${ }^{1}$ \\ February 1987}

B. Greenwald and J. E. Stiglitz

In this paper, we wish to set forth the outlines of a theory of macro-economic fluctuations based on informational imperfections in the capital market that we and some of our colleagues have been attempting to construct over the past few years.2

It has long been recognized that there is an important connection between money and the level of economic activity. Keynes entitled his famous treatise, The Genera1 Theory of Employment. Interest and Money, and more recent econometric studies have confirmed the existence of a relationship between money and economic activity. At the same time, this relationship has remained somewhat of a puzzle for economic theorists. The classical dichotomy suggested that the supply of money would affect the level of prices, but nothing real.

${ }^{1}$ Paper prepared for the Seminar on Monetary Theory, Taipei, January 3-8, 1986. An earlier version was presented at the CEME Conference on Banking, Nice, June 6, 1985. This paper was partially written while Stiglitz was a visiting scholar at the Hoover Institution, Stanford. Financial support of the National Science Foundation and the Hoover Institution is gratefully acknow ledged.

Parts of this paper report on joint research undertaken with A. Weiss and with A. Blinder.

2See, in particular, Stig1itz and Weiss [1981, 1983, 1985], Greenwald, Stiglitz, and Weiss [1984], Blinder and Stiglitz [1983], and Stiglitz [1978].

other parts of our research programme focus on the consequences of imperfect information for labor markets (see Stiglitz (1976, 1985, 1984a), Nalebuff and Stiglitz (1983), Weiss (1980), and Shapiro and Stiglitz (1985)); and for product markets (see, e.g. Stiglitz (1984b)). 
Much of macro-economic theory can be interpreted as an attempt to reconcile the classical dichotomy with the observed effects.

The Inadequacy of the Standard Theories

Traditional Keynesian analysis has stressed the importance of wage and price rigidities. With rigid wages and prices, an increase in the nominal money supply is equivalent to an increase in the real money supply. There are three mechanisms by which changes in the real money supply are thought to have an effect on the economy:

(a) The real balance effect: the increased "real wealth" of consumers leads to increased consumption, increasing aggregate demand and hence national income. Both the theoretical foundations and empirical relevance of the real balance (or Pigou) effect are suspect: since the money is debt which individuals owe to themselves, why should an increase in their real balances affect their behavior? 3 Indeed, a number of irrelevance propositions have recently been established, 4 which show that in an explicitly dynamic general equilibrium model in which people form (rational) ${ }^{5}$ expectations about the

${ }^{3}$ It is, of course, possible that the distribution of income changes, and any such changes in (either intra- or inter-tempora1) distribution may have real effects on the economy. The question is whether these distributional effects are significant enough to explain the magnitude of macro-economic fluctuations, and can they explain their patterns. In any case, these distributional effects have not been a central part of at least traditional explanations of how the real balance effect works.

"See, for instance, Stiglitz $(1982,1983)$ and the references cited there.

${ }^{5}$ Actually, the result does not depend on rational expectations, but on a rather weaker assumption, "consistent" expectations, where the expectations of certain key variables remain unchanged in the face of changes in variables (like the money supp1y) which are irrelevant to their determination. 
uncertain future, public financial structure is irrelevant.6 Any theorem is dependent for its validity on its assumptions: here, the key assumptions are (a) there is no redistributive effects of the change in public financial structure, either intra- or inter-temporally; (b) taxation is non-distortionary'; (c) there are no constraints on individuals' ability to borrow.

One of the central problems in macro-economic theory is differentiating among the many possible explanations of some phenomena: some "effects," though present, are undoubtedly of a sufficiently small magnitude to provide an unpersuasive explanation for the phenomena in question. Thus, almost any change in public financial policy has some redistributive effect, and there is likely to be some change in the aggregate dead weight loss arising from distortionary taxation. The question is whether these are important enough to explain the seeming potency of monetary policy; we suspect not.

More generally, the real balance effect, though undoubtedly present, seems a weak reed to rest at the foundations of any macro-economic theory: even at the fastest rate of deflation of prices, in the Great Depression, with plausible values of the wealth elasticity of demand for consumption goods, it would have taken more than a century for demand to be restored to its full

6 An increase in money supply, at fixed prices, is, at least in the standard theory, equivalent to an unancipated fall in prices, at a fixed money supply. Thus, if the former change has no consequences for the economy, neither should the latter. (This ignores certain important dynamic effects which we note briefly below.)

7 If taxation is distortionary, associated with any change in public financial structure there may be a change in the intertemporal pattern of tax liabilities, and this, in turn, may alter the aggregate deadweight loss associated with distortionary taxation. 
employment leve1. During that time, presumably, much else that is conventionally held constant in macro-economic models would have changed.

(b) The portfolio effect: with an increased holding of real money, individuals' portfolios are out of kilter; in the attempt to balance their portfolios, long term interest rates are bid down; and the lower interest rates induce greater investment.

This mechanism is also suspect on both theoretical and empirical grounds. Theoretically, the general Public Irrelevance Theorem argues that individuals ought to include their future tax liabilities in their portfolio calculations (these are uncertain, just as the returns from assets are uncertain); and when this is done, a change in public liability structure (e.g. an exchange of short term assets for long term assets) has no real effects. Empirically, what should be relevant for investment decisions, in the neoclassical analysis underlying most Keynesian and new classical economists' models, are variations in the real rate of interest, and these (as measured at least by traditional methods) are of a sufficiently small magnitude to provide an unpersuasive basis for cyclical fluctuations of the magnitude observed even in the post war period. Moreover, econometric studies have been strikingly unsuccessful at relating such interest rate fluctuations as exist to observed cyclical fluctuations in the various catagories of investment.

of course, the question remains, why did real interest rates not fall

Though we couch our discussion in terms of the effects on real interest rates, we could have equivalently presented it in terms of Tobin's "q". Then, we would have had to ask, how can we reconcile the seeming large variations in $q$ with the small variations in real interest rates? ( $q$ is affected, of course, by variations in expectations as we11; but how does monetary policy affect $q$ other than through effects on real interest rates?) 
more. The answer provided by Keynes, the liquidity trap, 9 is also unpersuasive, especially in our present inflationary environment; though it is no longer taken seriously, no alternative explanation of the failure of real interest rates to fall has gained general acceptance.

(c) Money as a medium of exchange: real money is necessary to facilitate transactions; with a decreased supply of real money, transactions are decreased. This is often modelled as a cash-in-advance constraint. The fact of the matter is that relatively few transactions require cash-in-advance; nor does the theory explain why there should be such a constraint. With perfect information concerning an individual's wealth, an exchange requires not the transfer of money for goods, but of credit for goods. ${ }^{\circ}$ In Italy, the shortage of sma11 change lead to the use of candy instead; though this may have had a beneficial effect on candy producers, it seems implausible that the shortage of coinage lead to major macro-economic effects.

The theory ${ }^{1}$ which we wish to expound today is premised on there being a

${ }^{9}$ In typical discussions of the liquidity trap, a set of inconsistent expectational assumptions are made. While the hypothesis that a consol sells for $1 / r$, where $r$ is the short rate of interest, requires an assumption of static expectations, the expectation that the price of a consol will fall when $r$ becomes very sma11 requires an assumption of "regression towards the mean" See Stiglitz (1970).

10 Nor is there a close link between the number of exchanges and the level of national income: most exchanges are exchanges of assets, of stocks, not of flows (of goods for labor services) The link between these two is seldom made clear in the standard theory.

${ }^{11}$ The above list of mechanisms by which monetary policy affects the economy is not meant to be exhaustive. An important 
close link between money and credit creation, and between credit creation and economic activity. We shall attempt both to explain why the links take on the form they do, and how this theory provides a more plausible explanation of several key phenomena which remain unexplained in the traditional paradigms.

\section{The Phenomena to Be Explained}

Among these phenomena are the rigidity of prices themselves: while

traditional Keynesian theory simply takes this price rigidity as

institutionally determined, this has always seemed unpersuasive; prices did

fall in the Great Depression. Why didn't they fall faster? To say that they

fell at the rate they did for "institutional reasons" seems to beg the

question.

A second "paradox" is the absence of much production smoothing over the

strand of recent literature stresses the informational consequences of monetary policy: on the one hand, producers may be unable to distinguish between monetary shocks and real shocks; hence, they respond to a perceived change in their nominal demand curve by increasing production; on the other hand, if monetary policy responds to certain signals (not otherwise observable), then monetary policy conveys information, and this too induces real responses from producers. Neither of these is very convincing: producers have available to themselves data both concerning monetary shocks (money supply figures are published in the newspaper weekly) and concerning real disturbances. And it seems implausible that the Governors of the Federal Reserve Board have access to much information that is not publicly available, other than that concerning what their own monetary policy in the future will be.

Still another strand notes that changes in monetary policy (in the rule that describes the rate of expansion of the money supply as a function of the state of nature) induce changes in the real return to holding financial assets; if individuals are risk averse, this will have real effects. (This argument requires that, in addition, there be inter-temporal redistribution consequences to monetary policy.) Though this effect is undoubtedly present, the question is, can it explain the magnitude and patterns of macro-economic fluctuations and the responsiveness of the economy to monetary policy? 
business cycle. If interest rates fell in a recession (or did not rise much), and shadow wages fell dramatica11y (as evidenced by lay-offs and unemployment), then, unless storage costs were very high, firms should find it desirable to increase their production and their inventory to sales ratios.

Similarly, investment and consumption both appear to be more volatile than can be explained by the observed fluctuations in real wages and real interest rates. 12

There are other phenomena to be explained, including the serial

correlation among key economic variables. ${ }^{13} 14$ We suggested in the previous

12 Assume, for instance, that real rates of interest remained at the low levels they were prior to 1980. Then, even an Individual who was temporarily unemployed would expect to lose a relatively small proportion of his 1 ifetime income, sufficiently small that it should have a negligible effect on his consumption. We should note that if aggregate consumption only depended on the "permanent income" of the aggregate economy, one might argue that quite the contrary, what is to be explained is why consumption is not more volatile; for if, as some have claimed, national income is a random walk, then consumption should accordingly vary approximately in proportion to income; and if, as others have claimed, disturbances are positively correlated (that is, a decline this period in national income, relative to trend, is likely to be followed by a decline next period), then the decrease in permanent income associated with a given decline in current income may exceed the decline in current income; and accordingly, the decline in consumption should be more than proportional to the decline in current income. This kind of aggregate behavior is consistent with individuals fully integrating the interests of their descendents (and all individuals having descendents; and if they do not have the same numbers of descendents, inter-family redistributions having no consequences.) We suspect that when adequate panel data is avallable, it will convincingly reject these hypotheses.

13 It 1s, in fact, fairly easy to construct models in which serial correlation arises: virtually any model with state variables will do. (Indeed, it seems a far more difficult task to construct persuasive models in which such serial correlation does not arise.) Thus, the task is to construct plausible models, in which the magnitudes of the serial correlation can be 
subsection that the seeming real effects of monetary policy is another

phenomenon to be explained by any adequate macro-theory; ${ }^{15}$ again, what has to be explained is not only the presence of these effects, but their magnitude and form, e.g. why contractionary monetary policies often seem more effective in inducing a curtailment of economic activity than expansionary monetary policies seem effective in speeding recovery from a recession.

\section{The Basic Premises}

The basic premises underlying our analysis are simple:

1. Many firms face credit constraints; thus, it is the availability of credit,

accounted for. Thus changes in the aggregate capital stock will give rise to serial correlation, but we suspect that the traditional Keynesian approach of ignoring these changes in capital stock, for short run analysis, is probably correct: the changes in the aggregate capital stock are just too small to account for the observed patterns.

We do not need to take a position here on whether there are regular business cycles, $i . e$. whether there is some property of the economy which systematically results in every boom turning into a recession, and every recession giving rise to the next boom; or whether the economy is simply continously being buffetted by shocks, the cummulative effects of which result in economic fluctuations.

14 There are also a host of labor market phenomena to be explained: not only the level of unemployment, but the pattern (who gets laid off) and the form (lay-offs rather than work-sharing.) Even if wages are rigid in some sectors, if there are sectors with flexible wages, we need to explain why unemployed workers do not seek employment in those sectors.

Some of these labor market issues are intimately connected with capital market problems, as we hint at below, and in Greenwald-Stiglitz, 1986. For a fuller discussion of these labor market issues, see, for instance, Stiglitz [1984, 1986].

15 While attention has focused on the correlation between money and output (or between unanticipated money shocks and changes in output), there are other correlations which may be equally--or more--significant, e.g. between credit (either some aggregate credit measure, as in Friedman [ ] or some intermediate credit measure, as in Nakamura [1986].) 
not the interest which firms have to pay, which restricts their investment; or when it is working capital which is curtailed, which limits their production. 2. Firms that are not credit constrained may still face an increase in the effective cost of capital, which induces them to reduce their investment. 3. Firms are constrained not only in the amount of capital which they can raise but also in the form in which they can raise it. Thus, they are frequently constrained from raising additional capital on the equity market. This means that the managers of firms cannot divest themselves of certain essential risks.

3. The absence of futures markets, combined with the limitations on equity markets,,$^{16}$ implies that every production decision is a risk decision. Thus, even in the absence of direct credit (borrowing) constraints, firms which unexpectedly find their working capital diminished (e.g., as a result of an unanticipated decline in prices) might choose to borrow less (or even if they borrowed more, they would not borrow enough more to compensate for the diminished working capital.) Accordingly, production will decrease.

4. In the short run, restrictions on high powered money may lead to restrictions on the availability of credit, and thus to lower output and inves tment.

5. There are important multiplier effects arising from credit constraints. While (4) explains why monetary shocks should have real effects, these multiplier effects explain why the economy may amplify any shocks which it recelves, whether real or monetary.

Underlying all of the analysis is the assumption that defaults on loans

${ }^{16}$ And the obvious fact that for most industrial production, there is a significant lag between the application of inputs and the sale. of output 
are a real concern of suppliers of credit; that there are significant costs to bankruptcy, so that (managers of) firms seek to avoid bankruptcy; ${ }^{17}$ that imperfect information, both concerning the assets and liabilities of borrowers and the actions which they take (all of which affect the likelihood and consequences of default), is pervasive; and that what information is available to one institution or individual cannot easily be transmitted to another.

The debt market. In our earlier work (Stiglitz and Weiss 1981, 1983, 1985) we showed that banks would, under a variety of circumstances, ration credit. It was shown that the return to the bank, per dollar loaned, might decrease with increases in the interest rate, either because the increase in the interest rate had an adverse effect on the mix of applicants, or because at higher interest rates, borrowers undertook riskier projects. Thus, it is possible that at an interest rate at which the demand for loans equals the supply (the Walrasian equilibrium), the return to the bank was lower than at lower interest rates; in such circumstances, the bank would reduce its interest rate and ration credit. Though the extent of credit rationing might be affected by other instruments available to the bank (such as collateral requirements), even these are, in general, insufficient to eliminate credit rationing. (There may be, for instance, important adverse selection effects associated with collateral.)

Banks and the debt market. Firms could, and do, issue debt directly; but a significant fraction of debt is mediated though banking institutions. Credit

17 In some instances, bankruptcy may impose little costs. We would argue, however, that the managers of most large corporations perceive themselves as facing a penalty if their firm goes bankrupt. 
rationing could, in principle exist whether there were banks or not. Assume a11 firms looked (to the untrained eye of the investor) identical, but the investor knows that the (expected) return per dollar loaned is higher at a 5\% interest rate than at a $7 \%$ interest rate. Clearly, he would buy bonds issued at the former interest rate rather than the latter, even though, as a result, there might exist an excess demand for funds at the $5 \%$ interest rate.

But banks exist both to screen applicants and to monitor the activities of the borrowers. The fact that the borrowers keep funds on deposit puts the bank in a position to monitor at least a fraction of the transactions of the borrower, and this may give him a signficiant information advantage. (To use the currently fashionable language, there may be important economies of scope between providing checking services and providing loans.)

The information gleaned by the bank on small borrowers may be particularly important; while information concerning General Motors may be relatively widespread in the economy, that concerning a sma11 widget producer is likely not to be. 18

The equity market. A natural question is why firms that are constrained in the debt market do not resort to the equity market. Information problems appear in that market as well. Indeed, banks, in making a loan to a firm, can both obtain more information and impose more restrictions than can a typical equity owner purchasing shares. (Free rider problems suggest that it will not

\footnotetext{
${ }^{18}$ We do not address here the question of why banks issue their liabilities in a form which makes them subject to runs, which may contribute in an important way to credit crises, and hence to economic fluctuations. But note that even if there were no banks, there can be credit runs, so long as there is short term debt.
} 
be in the interests of any shareholder, in a widely held firm, to obtain much information concerning the firm. (See Stiglitzig (1985b.)) Suppliers of credit must make inferences concerning their likely return to investing in a firm attempting to raise new capital through the equity market. Though there may be particular information relevant for a particular firm (e.g. that it has just made a new discovery, which it wishes to exploit), one of the inferences that may be made is that the firm has been unable to raise funds through the debt market, or that the terms at which the bankers are willing to lend to it are sufficiently onerous that the firm finds it desirable to seek funds elsewhere. Elsewhere (Greenwald, Stiglitz, and Weiss, 1984) we have constructed a simple, equilibrium model illustrating this; the firms that do resort to the equity market are "weaker" firms with both a high probability of bankruptcy (the terms at which suppliers of credit are thus willing to supply funds reflects this) and actual future earnings prospects which are low relative to their publicly observable characteristics (a fact assumed to be known to the firm's managers). Issuing equity provides a signal concerning the firm, one which has a deleterious effect (under specified circumstances) on the value of the firm. This deleterious effect has to be taken into account in the firm's decision to raise capital through the equity market. In some cases, it will induce the firm not to use the equity market at all, in which case the effective cost of capital is the cost of borrowing plus the cost associated with the increased probability of bankruptcy resulting from increased debt. In other cases, the firm may resort to the equities market, with the associated high cost of raising funds on $1 t$.

19 We argue there that banks have developed a set of institutional arrangements which mitigate these free rider effects. 


\section{Credit Markets and Cyclical Fluctuations}

In this section, we wish to explain how a shock to the economy leads to decreased investment, as a result of increased credit rationing, increased costs of raising funds on the equity market, and increased effective marginal cost of borrowing funds--taking into account the increase in the probability of defaultio (for those who can obtain credit). Consider, as an example, an unanticipated large increase in the price of oil. Conventional analysis has focused on the effects that this has on the value of different assets (those that are energy intensive users decreasing in value, those that are energy producers increasing in value.) But in addition, there are two important effects.

First, such an increase in price will usually redistribute equity both between firms on the one-hand and "investors" on the other and among firms. In the absence of complete futures markets, firms must usually pay for factors of production before the output produced by those factors is sold. These payments may in some cases, like working capital, occur only a year or less before the output is sold. In other cases, like large fixed capital projects financed by debt, the commitments to pay (and the terms of payment) may be determined many years before the output is sold. Any unanticipated changes in profitably which arise in the interim will (unless the firm goes bankrupt) be absorbed by the firms' equity stocks. Thus, higher than anticipated input prices and/or lower than anticipated final goods prices (or demand) will reduce the equity stocks

20 The marginal cost of borrowing includes a term reflecting the increase in the probability of default as a result of borrowing an additional dollar. Thus, what is of concern is how shocks to the economy effect the increase in the probability of default as a result of borrowing an additional dollar. 
of firms which provide a necessary cushion for both managements (and bankers) in absorbing the "risks" associated with future levels of production. In a perfect information world, the resulting losses of equity captial would be readily replaced by new equity issues. However, with restricted access to equity markets, firms can replace their now depleted equity stocks only slowly through higher retained earnings and other asset economies. In the mean time, output will be curtailed (with the associated phenomena of lay-offs and idle capacity) as managers are unwilling to bear the greater risks of bankruptcy associated with pre-existing levels of production supported by now depleted equity stocks.

The equity lost by some firms does not, of course, simply disappear. In a case like the oil shock, much of it goes overseas into the hands of oil producers. They, in turn, may reinvest it to the original firms. However, when they do so, this is likely for informational reasons to take the form of new debt rather than new equity to replace that lost through the initial price increase. The net result of this kind of recycling is unlikely, therefore, to alleviate the initial loss of equity.

A second group of beneficiaries of the oil shock may be other firms.21 However, the value of equity in absorbing the risks of higher production will, in general, be subject to diminishing returns. Thus higher output from equity gaining firms (e.g. oil companies) will only partially offset lower output from equity losing firms (with the magnitude of these effects being potentially far

${ }^{21} \mathrm{~A}$ third group of beneficiaries may be households. The consequences then are similar to those analysed above. Note, by contrast, in traditional neoclassical theory, all individuals can see perfectly through the corporate veil, so these wealth
redistributions have no effects. 
larger than pure wealth effects) and on balance productive activity may be reduced.

Exacerbating these effects, a second broad set of forces are brought into play by the destruction of "informational capital" associated with the original price shock. Lenders had gathered considerable information concerning the performance of various borrowers under the old regime; now, there is much greater uncertainty. They are unlikely to be well informed concerning the asset composition of the borrower, at least, not as well informed as the borrower. Thus, a shock such as this effectively increases the degree of asymmetry of information.

This in turn both decreases the supply of funds available for investment, and decreases the demand for investment at any interest rate.

Banks (and other lenders) respond to the increased uncertainty in three ways. First, they refuse to lend to some borrowers to whom they previously might have lent. This is illustrated in figure 1, where we have depicted the mean return to the bank as a function of the interest rate charged. Because of selection and incentive effects, there is an interest rate which maximizes the return to the bank. There is a curve such as this for every category of loans (where a category of loans is defined by the set of observable characteristics of the borrower, e.g. there would be a curve such as this for owner-occupied mortgages, another curve for a firm with a particular balance sheet, etc.) The shock is going to shift the curve; precisely how it shifts it depends on the precise nature of the shock. In particular, it may shift it downwards.

Assume that initially, the required rate of return on a loan is $p^{*}$; thus, the loan category depicted in figure 1 is just marginal. Now, even if after the shock the required rate of return is lowered, to $p \star \star$, the maximal return 
may be lowered even more. Thus, borrowers in this category will face credit constraints; they wi11 be unable to obtain funds.

Those that do obtain funds may find that the real interest which they are obligated to pay (providing they do not go bankrupt) may either rise or fall. In figure $2 a$ we depict a category of loans for which the rate of interest at which the return to the bank is maximized has increased, while in figure $2 b$ we depict a category of loans for which the rate of interest at which the return to the bank is maximized has decreased; in both cases, the increased uncertainty resulting from the shock to the economy has lowered the expected return to the bank at every rate of interest charged.

Secondly, even those that do obtain funds may find that the bank imposes stronger convenants than it previously did; it may insist on a shorter maturity to the loan. And it may be willing to lend less than it previously did.

Thirdly, of the funds available to the bank for investing, the bank may decide to hold more in the form of assets, such as government bonds, rather than in the form of loans. In our previous work, we modeled the bank as being risk neutral. But banks are, in many respects, like other firms; and the same arguments which suggest that managerial firms will act in a risk averse manner suggest that, in face of increased uncertainty, banks will respond by adjusting their portfolio. (To the extent that bankruptcy is costless, and banks maximize their own expected return, increased uncertainty may lead banks to undertake greater risk; depositors, knowing this, will - in the absence of insurance - tend to shun banks which do not act, or at least which do not seem to act, in a risk averse manner.)

At the same time, even good firms may reduce their demand for loans (at any interest rate), for two reasons. He postulated earlier that firms are 
risk averse, and that, in particular, their managers are concerred with

bankruptcy.22 In the absence of risk, bankruptcy is easy to define: it occurs whenever the present discounted value of the firms returns exceeds its

liabilities (i.e. its net worth is negative.) But, of course, in the absence of uncertainty, bankruptcy would never occur: no lender would ever lend so much that the firm would go bankrupt, and no borrower would ever borrow so much. Bankruptcy occurs in the presence of uncertainty. It occurs not when the present discounted value of expected returns to the firm are less than the liabilities--for the lender may not be able to capture enough of the returns in the goods states to compensate for the lack of returns in the bad states.23 Loan contracts are written in such a way as to give the lender the right to declare the loan in default in certain circumstances; these circumstances are "observable" conditions which reflect an expectation (at least from the perspective of the lender) that the firm will, with a reasonable probability, not be able to repay the loan, efther now, or sometime in the future. (Thus, a loan

22 Note that our concern is here primarily with the consequences of the anticipation of bankruptcy on economic behavior, rather than that of the bankruptcy itself.

In the absence of any informational problems, bankruptcy itself should give rise to no disruption to the economy; bankruptcy would then represent nothing more than a redistribution of ownership claims; the assets themselves are not destroyed by bankruptcy, and there would be no reason why they would not continue to be used in the most effective manner possible.

In fact, bankruptcy often represents a significant loss in organizational capital. Potential purchasers of capital goods know far less about each machine than its current owners, and it may take some time for them to learn about the appropriate disposition of the asset. Moreover, the occurence of bankruptcy may entail significant transactions costs; these include not only the lawyers fees, but capital which may be unused while ownership is being transferred.

\footnotetext{
23 For further discussion, see Stiglitz [1972] and Eaton-Gersovitz-Stiglitz [].
} 
can be declared in default even before it is due; the obvious reason for this is that there are sertous moral hazard problems which arise if the borrower believes that there is a reasonably high probability that he will go bankrupt; the firm may attempt to increase its returns in those states when it does not go bankrupt, at the expense of assets available in the event of bankruptcy.) There is some vagueness in this definition: after all, even when the loan is initially made, there is some probability of bankruptcy. For now, we can simply take the terms of the loan which define whether the loan is in default as given.

Given our assumptions concerning firms' aversion to bankruptcy, we can now explain why the shock may reduce its demand for investment. First, the shock may have a direct effect in increasing the uncertainty facing the firm, and, in particular, in increasing the probability of bankruptcy. Secondly, the shock may have an indirect effect in increasing the uncertainty facing the firm, as a result of the greater uncertainty facing its suppliers and those who purchase its goods. Any firm has a large network of economic relations on which it is dependent. There may be large costs if it does not receive its supplies of inputs in a timely way. Moreover, almost every firm is involved in providing trade credit. The firm is undoubtedly imperfectly informed concerning the effect of the shock on every supplier and purchaser. But the shock is likely to increase the probability that some purchaser would not be able to pay its trade credit; or that some suppller w111 go bankrupt, and fall to deliver some essential supply on time.

Thirdly, the firm may anticipate that even if it does not now face a credit constraint, it may do so in the future; or it may realize that it may be able to obtain loans only at very high interest rates, or with restricted 
convenants, which severely limit its discretion. The anticipation of future credit constraints may have effects similar to the current imposition of credit constraints.

Thus, the firm undertakes actions which decrease its probability of bankruptcy (e.g. reducing production); which decrease the probability of bankruptcy in the event of a future credit constraint; and which decrease the probability of the bank imposing credit constraints. The likelihood that a firm's bank will impose credit constraints (as well as the likelihood that the bank will declare a loan in default) is related to the firm's balance sheet. In looking at its balance sheet, the bank assigns greater weight to liquid assets, which can be easily evaluated and marketed, than to firm specific assets, about which there is greater uncertainty (greater asymetries of information.)

Firms attempt to Improve their balance sheets in two ways: by savings (i.e. by keeping their retained earnings in liquid forms) and by converting existing assets to more liquid forms, e.g. by reducing their inventories. They may also attempt to "1iquify" certain liabilities, where they perceive that the market may assign too much weight to them. Whether a trained worker is a net asset or a liability may be ambiguous; if an outsider views his skills to be of little relevance to the future activities of the firm, he is a liability, since there are always costs associated with discharging him.

Multipliers vs. dampeners; or prices vs. quantities.

These reactions to a shock give rise to multiplier effects which exacerbate the effect of the initial shock. In particular, it should be noted that not all firms can simultaneously liquify. The attempt by a producer to reduce its 
inventories of inputs reduces the demands facing its suppliers, and thus increases their probability of bankruptcy. Their increased probability of bankruptcy, in turn, increases the probability of bankruptcy for all those who have supplied that supplier with trade credit. All of these firms, facing greater uncertainty, reduce their demand for investment, and this in turn increases the probability of bankruptcy facing capital goods manufacturers, who therefore reduce their investment at any given level of real wages and real interest rates.

Credit constraints have similar multiplier effects. The credit constraints imposed on one firm reduce its demand for investment, which has repercussions on the demands facing other firms.

Multipliers abound in macro-economics. This is in marked contrast to micro-economics, where adjustment processes tend to dampen any initial shock. It is important to clarify what economic structures give rise to multiplicative effects, and what economic structures give rise to dampening.

For instance, in the ordinary demand and supply curve analysis (see figure 3) a shift in the demand curve by the amount dd (so at each price, demand has increased by dd) leads to an increase in prices; the new equilibrium level of output is higher, but by less than the amount dd. This dampening property is quite general in stable competitive price models.

It is the presence of information - related externalities (and wage and price rigidities) which gives rise to the multiplier effects. To see this, and to contrast these multiplier effects with the standard price responses, consider the following simple model. Let savings be an increasing function of the rate of interest, $S=S(r), S^{\prime}>0$. Assume initially that investment is only a function of the rate of interest, $I=I(r)$. (Recall that in neoclassical 
theory, it is only relative prices and price expectations which determine investment decisions, with a strictly convex technology.)

Equilibrium is at the point where

$$
I(r)=S(r) \text {. }
$$

Now assume that there is a perturbation, to say, the demand for investment curve by the amount $\alpha$, so

$$
I^{*}(r)=I(r)+\alpha .
$$

Then, in the new equilibrium, investment will have increased by

$$
\alpha(1-D), 0<D<1
$$

where $D$ is the dampening effect resulting from the change in the interest rate:

$$
D=I^{\prime} / I^{\prime}-S^{\prime} \text {. }
$$

Now assume that investment of firm 1 is affected by that of firm $j$ (as described above, as a result of the effect of each firm's decision on the probability of the other firm's bankruptcy.) Our investment functions now are of the form

$$
\begin{aligned}
I^{1}=I^{1}\left(r, I^{2}\right) & \\
I^{2} & =I^{2}\left(r, I^{2}, .\right.
\end{aligned}
$$

Assume, now, that $I_{1}$ shifts up by 0 . The now equilifbrium interest rate is given by the solution to

$$
S(r)=\delta+I_{1}\left(r, I_{2}\left(r, I_{1}+\delta\right)\right)+I_{2}\left(r, I_{1}+\delta\right)
$$

from which follows that in the new equilibrium investment will have increased by

$$
\delta[(1+n) /(1-m n)]\left[1-D^{*}\right]
$$

where

$$
\begin{aligned}
& n=\partial I_{1} / \partial I_{2} \\
& m=\partial I_{2} / \partial I_{1}
\end{aligned}
$$


and

$$
D^{*}=I^{1} /\left(I^{1}-s^{1}\right)\left(I_{1}^{1}(1+n)+I_{2}^{1}(1+m)\right) /(1-n m)
$$

The $D^{*}$ represents the dampening effect of interest rate changes, while $1+n / 1-m n$ represents the multiplier effect of the investment interaction. Thus, if interest rate effects are sma1l, the net effect is a multiplier one.

The multiplier effect may be seen more clearly in a special case of this mode1, where we can write

$$
I=M(r, I, 0)
$$

aggregate investment demand is a function of the interest rate and aggregate investment. Then, at any interest rate,

$$
d I / d 0 ́=[\partial M / \partial 0 ́][1 / 1-\partial M / \partial I]
$$

Thus, so long as the indirect effect is positive, but not greater than 1 (i.e. $\partial M / \partial I<1)$, there is a multiplier effect on the investment demand curve. A similar multiplier analysis applies for the credit multiplier.

Welfare multipliers. We have focused our attention on an explanation for why a shock to the economy may be amplified, rather than dampened, why the final change in output may be a multiple of an initial change in, say, demand. We should note the more general prevalence of welfare multipliers. Whenever the economy is not at a pareto optimal allocation, small perturbations to the system may result in large (relative to the size of the initial perturbation) welfare gains. In particular, a perturbation which has a small effect on the welfare of a particular individual, or the profits of a particular firm, may have significant welfare effects on the economy as a whole. 24 Elsewhere, we work.

\footnotetext{
24 Akerlof and Yellen have emphasized this in their recent
} 
have shown that in fact economies with informational imperfections are almost always (constrained) pareto inefficient. 25

Cyclical variability in the cost of capital. The multiplier effects that we have described in the previous section may lead to a significant increase in the effective cost of capital during a recession. Consider a firm which is not constrained by its bank. Its effective marginal cost of borrowing includes the direct cost plus the indirect cost associated with the increased probability of bankruptcy resulting from increasing borrowing. Even if the real interest rate charged by banks does not increase, the indirect cost may have increased significantly. Similarly, its effective cost of borrowing will increase if it anticipates a higher probability of being credit constrained in the future. Likewise, consider a firm which is presently credit constrained. It has the option of raising funds in the equity market; but the recession may lower the expected returns associated with raising those funds on the equity market, and this may increase the effective cost of capital raised in that manner. (In any case, there is an effective kink in the supply of capital schedule; raising capital on the equity market, as we have noted, provides a signal, which adversely affects the value of the firm; thus, many firms which are excluded from the debt market simply reduce their investment, limiting it to retained earnings.)

25 Though our 1986 paper established this only for economies with market clearing, subsequent work has confireed these results for economies in which there is unemployment and credit rationing. 
Wage/price rigidities. Wage/price rigidities have not played a very important role in our exposition. In fact, falling prices may exacerbate the problems we have noted, particularly if contracts are not fully indexed. For falling prices increase the real value of liabilities and thus increase the probability of default of all firms with unindexed net liabilities. Moreover, even if liabilities were indexed, falling prices will lead to an increase in the real interest rate ${ }^{26}$; and this too will increase the probability of bankruptcy of many firms. ${ }^{27}$

Credit and the Quantity Theory of Money. In recent years, there has been considerable controversy between the "quantity theorists" and Keynesian economists. The former claim that it is the quantity of money which directly affects the economy; the latter that the quantity of money only affects the economy through interest rate effects. The problem has been that neither theory seems really credible: while the quantity theorists have offered no really plausible mechanism to explain how the quantity of money directly

\footnotetext{
${ }^{26}$ Assuming, of course, that the nominal interest rate remains unchanged. The Public Financial Irrelevance Theorems (Stiglitz, 1982,1983) establish conditions under which changes in the rate of inflation have no real effects. In the context of our mode1, perfect indexing would require not only indexing of all financial contracts, but also a full set of future markets, which would enable firm managers and owners to divest themselves of all risks arising from the lag between inputs and outputs.

The fact of the matter is, of course, that there is imperfect indexing; and as long as that is the case, falling prices may exacerbate the problems with which we are concerned here.

27 Though it may decrease the probability of others, it increases uncertainty and asymmetries of information, and 1 is these which give rise to the problems which are of concern here.
} 
affects the economy, ${ }^{28}$ the variations in the real interest rate have been

(except in recent years) of sufficiently small magnitude as to raise doubts whether they play an important role in controlling, say, the level of

investment or consumption (and, in any event, such variations in real interest

rates as occur do not appear in econometric models to explain very successfully

variations in investments). Our theory agrees with the monetarists, arguing

that variations in real interest rates are not necessarily central; but it

provides a mechanism--through the control of credit--by which monetary policy

can directly affect the level of economic activity. 2930

28 See our earlier discussion for why we find some of the alleged mechanisms unpersuasive. Further doubt on the transactions mechanism has been raised by recent financial innovations, which have facilitated the ability of individuals and firms essentially to write checks against a wide variety of assets.

29 The monetary authorities directly control only the credit made available by banks. But because of the specific information concerning borrowers which banks have acquired, the cost of acquiring funds from other sources (such as on the equity market) will, in general, be higher than acquiring funds from the bank. Thus, restricting bank credit may markedly increase the marginal cost of funds to borrowers, even if the bank does not markedly increase the interest rate it charges.

A question is sometimes posed, why do not banks open up an equities subsidiary, to make use of the information acquired by the bank. First, the information acquired by the bank is particularly concerned with the bottom tail of the distribution of returns, the states in which the firm may go bankrupt.

Secondly, it is easier to impose convenants on loans than on equities, and since the bank cannot control the actions of the firm through its equities subsidiary as effectively as it could when extending credit, it may only be willing to invest at terms that the firm finds unattractive. Thirdly, the fact that the bank is not willing to lend to the firm, but is willing to invest in equity, provides information to the market which may have a deleterious effect on the firms market price.

3oOur model also provides an explanation for why government financial policy is not irrelevant: government and individual borrowing are not perfect substitutes, so long as future recelpts from the government are not collateralizable. 
This is not the occasion to detail the determinants of the amount (and terms) of credit which the banking system makes available, or the mechanisms by which the monetary authorities affect the level of credit made available by the banking system. Here, we simply note three points:

(1) The banks are, in many ways, like other firms in the economy; when their working capital is reduced, their willingness to lend (which is, after a11, their "production activity") is reduced.

(2) In a decentralized economy, there is no reason that the aggregate amount of credit made available by the banking system will necessarily equal either the supply of investment goods or the level of (full employment) savings at current prices. ${ }^{31}$ In traditional neoclassical models, the interest rate would adjust to ensure that (full employment) equilibrium is attained; in our model the real interest does not vary much, and should not play an important role in the equilibration of the economy. When the aggregate amount of credit is insufficient, so that prices fall in an unanticipated way, working capital may be destroyed, and this will have, as we have argued, real effects on the economy.

(3) Our theory is consistent with the observation that monetary policy may be more effective in curtailing economic activity in a boom than stimulating it in a recession; in a recession, banks may be unwilling to lend, and firms may be unwilling to borrow (banks frequently have free reserves in the depths of a recession.)

31 One might be tempted to suggest that this "coordination" failure could be alleviated by having one central bank make all loans. But this ignores the central information problem with which banks are concerned: who are the good borrowers, those who are most likely to repay the loans. 
Consequences of increasing real cost of capital. The hypotheses that the effective real cost of capital increases in a recession, and that firms attempt to 1iquify their balance sheets, provides a natural explanation of several of the until now unexplained patterns of business cycles.

Our analysis has provided an explanation of why investment and consumption fluctuate more than they should, given the limited variation in real wages and real interest rates (as distinguished from the real effective cost of capital, which we have argued does increase dramatically during a recession.) Indeed, even abandoning the neoclassical framework and resorting to a more Keynesian framework in which firms face output constraints and workers constraints on the amount of labor they can sell, we conjecture that the observed variations in consumption and investment can still not be fully accounted for. Our model provides such an explanation: it is not the observed real interest rate which is of relevance; rather, it is changes in equity - working capital - combined with the attempt by firms simultaneously to "liquify" their balance sheet which leads to a marked decrease in investment (and an associated marked increase in the real effective cost of capital.) Moreover, we have provided a multiplier process which multiplies the consequences of any shock. ${ }^{32}$

32 Though we have focused our attention on firms, a similar analysis applies to individuals. Some individuals will face credit constraints. Other individuals, fearing future credit constraints, will attempt to "liquify" their position, by saving more, by postponing the purchase of durables, etc.

There is another aspect of these cyclical fluctuations which should be noted. The question of replacing durables (or purchasing any investment good) can be posed as a question of optimal timing. If the firm or consumer has chosen his time optima11y, then the loss in profits (welfare) from postponing a repurchase is a second order effect; on the other hand, we have argued that shocks typically increase the degree of uncertainty facing a firm; if it is equally likely that the shock has decreased or increased the optimal date, and if some of the uncertainty about which has occured will be resolved in the near 
Similarly, our analysis explains what would otherwise appear to be an anamolous pattern of inventory accumulation and production. One of the most widely observed phenomena of recesstons is labor hoarding: workers seem underutilized. This translates into a very low shadow value of their time. This, combined with the underutilization of capital, suggests that the cost of production are markedly lower in a recession than in a boom. Given plausible estimates for storage costs and taking the observed real interest rates as the effective cost of capital, one would be lead to expect marked increases in inventories (absolutely, as well as relative to sales) during recessions, and that these would actually increase as the economy starts to move out of the recession (since then the anticipated holding period of such inventories would be down.) The actual pattern can only be explained by a significant increase in the effective cost of capital in the recession, as our theory claims is the case.

Similarly, our theory explains why unemployed individuals may not be willing to accept jobs at prevailing wages in a recession, when those jobs entail high training costs, borne by either the firm or the worker. For both, the implicit cost of capital in a recession may be very high. Thus, for instance, the life time wages that a firm that hires a worker requiring training $\operatorname{costs}^{3}$ in the depths of a recession may be willing to pay may

future, then it will pay the firm to postpone the decision. There is an "option" value to postponement, which is increased as a result of any shock.

Though potentially important, we suspect that this cannot fully explain the observed patterns of investment, consumption, and production: the reduced cost of production in the recession are sufficiently great to outweigh the increase in option value.

${ }^{33}$ Moreover, the worker is also likely to be unwilling to deplete his savings to finance the training costs, at such times when he is more likely to face a financial constraint and 
actually be less than the life time wages than if it should hire the worker

1ater. Moreover, workers may be unwilling to accept current low wages for high future promised wages; those promises are like equity loans, since firms do not have fixed commitments; and the arguments for why suppliers of capital are unwilling to provide equity loans apply with equal force here. ${ }^{34}$

\section{Comments on Alternative Theories}

Before concluding, we wish to remark on some of the salient differences between our theory and some of the major competing alternative hypotheses. We have already indicated what we believe to be some of the crucial inadequacies of the standard neoclassical theories' attempts to explain the real effects of money, ${ }^{35}$ and we have suggested that those models, with their implied absence of a corporate veil, simply cannot explain the cyclical movements of the key economic variables, let alone the persistence of unemployment.

when such investments appear to be particularly risky. See below.

${ }^{34}$ See Greenwald-Stiglitz, 1986 for a more extended discussion of these issues.

35 We do not discuss here the rational expectations theories. Host of the results of those models depend not so much on the assumption of rational expectations, as on the assumption of market clearing; we would argue that one of the central objectives of macro-economics is to explain unemployment--the seeming failure of the labor market to clear; a theory which assumes away unemployment thus has little chance of throwing much light on the central issues. We should note in passing however that without market clearing assumptions, rational expectations may actually increase the effectiveness of government policy, e.g. by increasing multipliers (Neary-Stiglitz (1982)); and that nowhere in our analysis do we require non-rational expectations; our analys is of, for instance, cyclical movements in investment does not require the simple kinds of extrapolative expectations formation that underlies the usual analysis of the accelerator. 
Keynesian Theory. In many respects, our theory has a close affinity to traditional Keynesian analysis. Variability in investment, and the inability of investment to be stimulated by normal market forces, were central to his analysis.36 But Keynes never found an adequate explanation for this; he was forced to rely on "animal spirits" to explain the level of investment; and on the now discredited liquidity trap to explain why interest rates could not fa11.

His problems arose from two sources. First, he was too much of a neo-classical economist (though whether he would have recognized this epithet is another matter.) Thus, he wanted to rely on adjustments in the rate of interest as the equilibrating mechanism. He did not see the central role that financial structure played. This led him into a series of modelling mistakes: he aggregated equity and bonds together, thus failing to observe the critical differences in the risk properties associated with these two forms of raising capital; he focused on flows, thus failing to observe the critical role played by the balance sheet (stocks) in determining firm behavior; and he followed the Marshallian tradition of focusing on a representative firm, thus failing to recognize the consequences arising from a redistribution of the stock of working capital among firms.37 (Indeed, several commentators on an earlier version of this paper noted that Kalecki might more properly be given credit as the antecedent of the theory expounded here. (See Kalecki [1939].)

Keynes was again correct in his conclusion that money could have real

36 Thus, those fixed price models (such as Malinvaud [1977]) which have focused almost exclusively on wage rigidities seem to us to leave out an important part of the Keynesian story.

${ }^{3}$ Simflar criticisms could be leveled at his analysis of aggregate consumption. 
effects on the economy, but the mechanism he sketched was again too tied to his Cambridge roots. He ignored a long literature attempting to relate the monetary system and credit availability, and it is in this tradition that our theory has its real antecedents.

Flexible Prices

Wage/price rigidities were central to Keynes. We believe that these rigidities are important. But it should be noted that they have not played a very important role in our exposition. In fact, falling prices may exacerbate the problems wo have noted, particularly if contracts are not fully indexed. For falling prices increases the real value of 1labilities, and thus increases the probability of default of all firms with unindexed net liabilities. Moreover, even if liabilities were indexed, falling prices will lead to an increase in the real interest rate; and this too will increase the probability of bankruptcy of many firms.38

Fina11y, our analysis provides part of the explanation of price rigidities. It has long been recognized that the Walrasian auctioneer may provide a very misleading model of the process of price adjustment. Firms set their prices, even in fairly competitive environments. In setting their prices, they are concerned not only with the effect on their current customers, but also with the recruitment of customers. (Because of costly search, not a11 Individuals are searching intensively a11 the time.) By raising their prices, they may make more profits out of current customers, but recruit fewer new customers. There is an intertemporal trade off; and an increase in the

\footnotetext{
3s Though it may decrease the probability of others, it increases uncertainty and asymetries of information, and it is these which give rise to the problens which are of concern here.
} 
effective cost of capital tilts the balance towards current profits: firms become less concerned with recruiting new customers. ${ }^{39}$ This results in an increase in the mark-up over marginal costs. Thus, even if wages are falling, prices are likely not to fall as fast.

\section{Concluding Remarks}

A central problem of economic theory for the last fifty years has been the attempt to reconcile macro-economics with traditional micro-economic theory. The latter, while providing a simple and seemingly persuasive theory of the firm and consumer, predicts that there should be full employment. The inconsistency between that prediction and the periodic episodes of unemployment In virtually all capitalist economies suggests something--something major--is wrong with that theory.

Samuelson attempted something of a sleight of hand by introducing what he called the "neoclassical synthesis", In which he argued that there were two regimes to the economy, an unemployment regime and a full employment regime. Though neo-classical principles clearly did not apply to the former, once the government had restored the economy to full employment, the relevance of neo-classical analysis was simultaneously restored. No convincing argument was ever put forward for this neo-classical synthesis: why should whatever the imperfections in markets, the underlying causes, simply disappear when the level of economic activity increases? Is it not more plausible that they remain, that recessions are simply the most obvious and undeniable

39 See Phelps and Winter [1976]. There are, of course, other explanations of price rigidities, some of them again based on asymmetries of information. For a survey, see Stiglitz,
1984 . 
manifestation of pervasive departures from the neo-classical paradigm?

More recent attempts by the fixed-price models, though going in the right direction, are similarly inadequate. They simply postulate wage and price rigidities, without explaining them. Why should firms, operating in the competitive manner postulated, solving quite complicated intertemporal maximization problems, not lower their prices in the face of excess supply? The underlying hypotheses are at best ad hoc, at worst inconsistent. Moreover, recessions cannot be accounted for by the rigidity of real wages alone: in the absence of large supply shocks, or inexplicable changes in preferences for leisure versus income, the Walrasian real wage should vary very little (just as market real wages vary little over the cycle.) Implicitly, then, most versions of the fixed price model attribute the disequilibrium to too high a level of money wages and prices. This suggests that a fall in money wages and prices would restore equilibrium.

Here, we have to agree with Keynes: whether Keynes considered the real balance effect or not, from our current perspective it is clear that it is empirically irrelevant; and indeed, if falling wages and prices generate expectations of further declines in wages and prices, even within a neo-classical perspective, the short run effects on income and employment may be deleterious ${ }^{\circ}$. But Keynes seemed to suggest that these decreases in money wages and prices would, themselves, directly have a deleterious effect on the economy. We have provided a model which explains why this is so.

The reconciliation of macro-economics with micro-economics requires more than just an ad hoc adaptation of the standard Walrasian model. The failures of that model run deeper than just its failure to be able to explain phenomena

40 See Neary and Stiglitz [1983]. 
of such central importance as unemployment. It requires the revision of that model, taking into account the central role that information, and imperfections in information, play. Not only will this enable the development of a consistent macro and micro-theory; but both the macro-theory and the micro-theory will be better than the current competitive paradigm, which systematically ignores these considerations.41

We hope that, in this paper, we have at least convinced you that informatinal imperfections provide the basis of a consistent explanation for many hitherto unexplained aspects of macro-economic behavior.

${ }^{4}$ For a survey of some recent work attempting to construct such a theory, see J. E.Stiglitz [1985]. 


\section{References}

Blinder, A. and J.E. Stiglitz, "Money, Credit Constraints and Economic Activity", American Economic Review, May 1983, pp. 297-302.

Friedman, Benjamin M., "The Roles of Money and Credit In Macro economic Analysis", Working Paper No. 831, National Bureau of Economic Research, December 1981.

Greenwa1d, B. A. Weiss and J.E. Stiglitz, "Informational Imperfections in the Capital Markets and Macro-economic Fluctuations", American Economic Reviex, May 1984, Vo1. 74, No. 2, pp. 194-200.

Kalecki, M., Essays in the Theory of Economic Fluctuations, New York, Russe11 and Russe11, 1939.

Keynes, J.M., The General Theory of Employment. Interest and Money, (London: Macmillan \& Co.), 1961.

Malinvaud, E., The Theory of Unemployment Reconsidered (Oxford: B lackwe11, 1977).

Nalebuff, B. and J.E. Stiglitz, "Equilibrium Onemployment as a Worker Selection Device", mimeo, Princeton University, 1983.

Neary, P. and J. E. Stiglitz, "Towards a Re*construction of Reynesian Economics: Expectations and Constrained Equilibrian, Ouarterly Journal of Econonics, Supplement 1983, pp. 199-228.

Phelps, E. S. and S. G. Winter, "Optimal Price Pollcy Under Atomistic Competition" in Microeconomic Foundations of Employment and Inflation Theory, E. S. Phlps, ed., W. W. Norton and Co., N.Y., 1970.

Shapiro, C. and J.E. Stiglitz, "Equilibrium Unemployment as a Worker Discipline Device", American Econonic Revier, June 1984, Vol. 74, No. 3, pp. 350-356. 
Stiglitz, J.E., "A Consumption Oriented Theory of the Demand for Financial Assets and the Term Structure of Interest Rates", Review of Economic Studies, Vol. 37, July 1970, pp. 321-251 (presented at the August 1968 meetings of the Econometric Society, Boulder, Colorado).

Stiglitz, J.E., "Some Aspects of the Pure Theory of Corporate Finance: Bankruptcies and Take-overs", Bell Journal of Economics and Management Science, Autumn 1972, pp. 458-482.

Stiglitz, J.E., "Prices and Queues as Screening Devices in Competitive Markets", IMSSS Technical Report No. 212, Stanford University, August 1976.

Stiglitz, J.E., "Lectures in Macro-economics", mimeo, Oxford University, 1978.

Stiglitz, J.E., "On the Relevance or Irrelevance of Public Financial Policy, NBER Working Paper No. 1057, April 1982.

Stiglitz, J.E., "Ownership, Control and Efficient Markets: Some Paradoxes in the Theory of Capital Markets", in Economic Regulation: Essays in Honor of James R. Nelson, Kenneth Boyer and William Shepherd eds., (Ann Arbor, Michigan: Michigan State University Press, 1982, pp. 311-341.

Stiglitz, J.E. "On the Relevance or Irrelevance of Public Financial Policy: Indexation, Price Rigidities and Optional Monetary Policy", in Inflation, Debt and Indexation, R. Dornbusch and M. Simonsen, eds., M.I.T. Press, 1983, pp 183-222.

Stiglitz, J.E., "Price Rigidities and Market Structure", American Economic Revien, May 1984, Vol. 74, No. 1, pp. 350-356.

Stiglitz, J.E., "Theories of Wage Rigidity", NBER Working Paper No. 1332, September 1984. 
Stiglitz, J.E., "Competivity and the Number of Firms in a Market: Are Duopolies More Competitive Than Atomistic Markets", mimeo, Princeton University, October 1984.

Stiglitz, J.E., "Information and Economic Analysis: A Perspective", Economic Journal Supplement, Vo1. 95, Spring 1985, pp. 21-42. (Paper presented at the Annual Conference of the Association of University Teachers of Economics, University of Bath, 1984).

Stiglitz, J.E., Credit Markets and the Control of Capita1", Journal of Money. Credit and Banking, May 1985, Vo1. 17, No. 2, pp. 133-152.

Stiglitz, J.E., "Equilibrium Wage Distribution", Economic Journal, September 1985.

Weiss, A., "Job Queues and Layoffs in Labor Markets with Flexible Wages", Journal of Political Economy, 1980, 88, pp. 526-538.

Weiss, A. and J.E. Stiglitz, "Credit Rationing in Markets with Imperfect Information", American Economic Review, June 1981, Vo1. 71, No. 3, pp. 393-410.

Weiss, A. and J.E. Stiglitz, "Incentive Effects of Termination: Applications to the Credit and Labor Markets", American Economic Revien, December 1983, Vo1. 72, pp. 912-927. Weiss, A. and J.E. Stiglitz, "Credit Rationing and Collateral", mimeo, BellCore, 1984. 